\title{
Dangerous Moods: Public Opinion and Mass Communication in the Czech Lands of the 18th Century
}

\author{
KATEŘINA SOUKALOVÁ* - JIŘÍ ŠUBRT**- \\ JAN ŠTEMBERK***
}

Nebezpečné nálady: Veřejné mínění a masová komunikace v českých zemích v 18. století

\begin{abstract}
This article deals with the advent of mass communication and the formation of public opinion in the Czech lands in the 18th century. It traces the gradual penetration of Enlightenment ideas, the development of intellectual life in aristocratic salons, the beginnings of Czech theater, currents of opinion in the folk environment, and the birth of Czech journalism. Specific attention is paid the French Revolution and its reflection in the Czech environment. The article deals with unofficially disseminated information, censorship of the press, surveys of the mood of the population, and contemporary legends among the people. It shows that the observed period began to give birth to modern public opinion in the Czech lands.
\end{abstract}

Keywords: 18th century; Enlightenment; public opinion; mass communication; newspapers; the mood of the population; folk rumours

DOI: $10.14712 / 23363525.2020 .17$

Public opinion is a social phenomenon linked above all to the areas of social control and politics. Before we turn to the problem in detail, let us make some preliminary notes which relate to the way this phenomenon is described in sociological literature.

Some sociologists consider public opinion a phenomenon that can be found in every society; others see it as a modern phenomenon, the origins of which date to approximately the 18th century. The term public opinion is itself a modern one and was first used in the 18 th century (authorship is ascribed to J. J. Rousseau) in connection with the social and political emancipatory tendencies of that time.

The history of public opinion was examined in the 1920s and '30s by Wilhelm Bauer [1930; 1934], author of the book Public Opinion in World History. He followed developments back to the ancient world, pointing to several concepts which in different historical periods covered the meaning understood today by the term "public opinion" (for example fama, rumores, vox populi, publica voce etc.). Regarding modern public opinion, Bauer paid special attention to the problems of the development of the modern political press.

The study of this wider sense of public opinion from a historical perspective, of course, brings with it the problem of comparison. This has been differently evaluated and perceived through history, and the same applies to phrases and concepts. According to Jackob

\footnotetext{
* Mgr. Kateřina Soukalová, Ph.D., was a doctoral student in Prague, at the Faculty of Humanities, Charles University, 2013-2017.

** Doc. PhDr. Jiř́ Šubrt, CSc., Faculty of Humanities, Charles University, Pátkova 2137/5, 18200 Praha 8. E-mail: Jiri.Subrt@fhs.cuni.cz

*** Doc. JUDr. PhDr. Jan Štemberk, Ph.D., Faculty of Humanities, Charles University, Pátkova 2137/5, 18200 Praha 8. E-mail: Jan Stemberk @fhs.cuni.cz
} 
[2007: 294] there are four different historical conceptions of public opinion, connected with various historical stages. First, there is the traditional approach associated with the intellectual history of public opinion from antiquity to the Enlightenment. Secondly, there is the Enlightenment (classic) concept connected with the influence of the intellectual elite and the development of modern democracies in the 18th century. The third concept is the concept of the masses which developed with the industrial revolution in the 19th century. The fourth concept relates to modern questionnaire surveys, which began in the first half of the 20th century.

A specific view of public opinion was provided by the French sociologist Gabriel Tarde [1901] in his book Opinion and Crowd. Tarde linked the development of public opinion with two events, both of which he located in the 18th century: a) the emergence of a public - initially as select literary, philosophical and other publics and b) the transformation of private discussion conducted in 18th century salons into public discourse hosted by newspapers. G. Tarde links the expansion of public opinion in the 19th century with the development of the mass media and communication, especially the press, railways and telegraph. The most important instrument of public opinion was the press, an instrument which forms (creates) public opinion while being the product (reflection) and therefore the result of the same public opinion.

A similar view appears later in the book Structural Transformations of the Public by Jürgen Habermas [2000], which deals with the process of the transformation of the so-called representative public of the late Middle Ages, into the civic public, a transformation carried out through the emancipation enshrined in bourgeois revolutions in salons and cafes, which forged a literate public.

This study deals with an example of the formation of public opinion in a social environment, which had its specifics in comparison with other European countries, and thus occurred in ways somewhat different from the theoretical explanatory models outlined above.

\section{The Spirit of the Times (Zeitgeist) and the Czech Lands}

The 18th century was an important milestone in the history of Europe in the economic and social fields, and it influenced the Czech lands. Naturally this century was important also in the area of the emergence and strengthening of new ideas, which apart from other things resulted in two great revolutions in the last quarter of the 18th century - the American Revolution and the French Revolution. A substantial factor in the mentioned new intellectual currents was the development of the phenomenon of public opinion.

Besides England, with its philosophical traditions of empiricism and stress on the individual freedom of citizens, expressed in British parliamentarianism and in the emergence of the classical British constitutional monarchy, it was above all France, at that time the main military and colonial power, that became the cradle of new ideas and therefore of public opinion. The fact that France was a cultural "superpower" was important as well. French, to a great extent, had replaced Latin as the language of educated people. Through French the vogue ideas of the Enlightenment were carried east to Russia and west to North and South America.

New currents of thought in France can be traced back to the second half of the reign of Louis XIVth, at that time the main representative of absolutism. This coincided with 
the so-called crisis of European consciousness, when in the intellectual circles of Western Europe doubts about the main pillars of faith and thought began to appear. The methodological principle of René Descartes, who believed it necessary to doubt everything, replaced old ways of thought. The authoritative assertions of secular and religious authorities were subjected to a "trial of reason", and tradition was losing its hitherto magical power. Holy Scripture itself was becoming a subject of historical and philological criticism. The ideas of deists, pantheists and mechanical materialists started to spread.

The intellectual world gained strength from the ideas of the Enlightenment (Lumières, Aufklärung, illuminisimo, просвещение), which, in contrast to the "dark Middle Ages", stressed the victory of reason and critical intellect. The views of "enlighteners" started gradually to form public opinion, spreading through cafes and clubs, and the salons of upper-class women, where political and economic questions were discussed.

A powerful instrument for the promotion of Enlightement views was The French Encyclopedia or Rational Dictionary of Sciences, Art and Crafts (Encyclopédie ou Dictionary raisonné des sciences, des arts et des métiers, 1751-1780). This had a great impact; its volumes were circulated around royal courts, placed in decorated palace libraries and frequently read even by the clergy. The Encyclopedia provided enlightened public opinion with an impulse for further deliberation. It supplied the public with a conviction that mankind, thanks to reason, was embarked on a path to progress that was observable in the field of science, but had yet to be felt in politics (through freedom) and in religion (through tolerance). The Czech lands, at that time a part of the Habsburg Empire, did not escape the influence of these new currents of thought [Haubelt 1986], though they were strongly affected by their specific situation. Among the factors which influenced public opinion in the 18th century in Czech society were: 1. the influence of the Roman Catholic Church, 2. the salons of aristocrats (Counts Nostitz, Lazansky, Sternberg), 3. the ideas of the national revival, including national literature, 4 . the emergence of the first scientific societies, 5. the press, 6 . the influence of foreign ideas and propaganda, 7. the theatre.

The institution best placed in the 18th century to influence the views of Czech society, collectively and individually, from cradle to the grave, was without doubt the Roman Catholic Church. According to the Renewed Land System of 1627 (in Moravia 1628) Catholicism was the only religion allowed for all the estates and inhabitants of the Czech Kingdom, with the exception of the Jews. This situation was not substantially affected even by the Patent of Tolerance of Emperor Joseph II on 13th October 1781. The importance of the clergy was well-known to Joseph, who tried to turn them into civil servants sui generis. Inside churches, Imperial Acts and other state documents were read from the pulpits.

Roger Chartier [in: Madl - Tinková 2012: 15] argues that the concept of the public radically changed between the 17th and 18th centuries. The baroque political scene was heterogeneous and hierarchical; it consisted of members of all estates, both from the nobility and the people, but it was not a modern public capable of creating public opinion, as it was manipulated by royal and political powers. It was a passive public, accepting everything and believing everything. But at the end of the 18th century things changed the general public rejected deception and clearly called for openness and transparency in political and social issues. It carried the political debate, as well as private matters, into a public arena, aiming at truth and expecting a fair settlement. But this new public was not a public of all members of society, because enlightened intellectuals excluded those 
outside literary, philosophical and political elites, which meant that the new public excluded people deemed insufficiently enlightened, and lacking in rational thinking and clarity of judgment, and excluded true public opinion as being opposed to opinion based on the informed and rational mind.

In this connection, an interesting question is how the common people were viewed by the upper strata of society. Philanthropically-orientated noblemen like the Franz Josef Count Kinsky were an exception. The opinion of a considerable part of the Czech nobility for the entire 18th century was more or less scornful and dismissive. The "malicious peasant" was seen as an individual to be loathed, partly for reasons of aesthetics and hygiene.

Authors defending the peasants complained that higher society looked at common people as a "towing beast, creeping on", to be avoided. For them it was an "unclean creature, stinking and with the tendency to be lazy, defiant, hypocritical and unjust" [Kutnar 1948a: 92]. Lowering themselves to the level of the peasant was below the human dignity of members of high society. The opinion of the common people was therefore considered worthless and absolutely irrelevant. Such people were still considered stupid, irrational and incapable of critical discussion. The enlightenment perceived their opinion as a source of irrationality against which only the vigilance of State security could prevail. Such an understanding of the relationship between the opinion of the people and authority can be found in the Encyclopaedia of 1751 [Neubauer 1992: 132].

The reforms of Enlightened absolutism significantly disrupted the structure of feudal society. The dominant position of the nobility was shaken by emancipation of the urban population as well as the rural one. Reform measures also affected the social situation, on the one hand, aiming at further deepening of the reforms that had brought together hitherto strictly separated classes, while raising fears among the privileged of further development. The emancipation of the lower classes even brought with it a shift in their thinking. The reform measures contributed to the growth of self-confidence of the lower classes, relying with growing confidence on the state and in a sovereign who actively entered into relationship with its subjects. The abolition of serfdom proclaimed by Joseph II, not long after his accession to the throne, significantly affected the Czech rural area. This and other reforms brought Joseph II significant popularity among the rural population, among whom spread news about the success of appeals against seigniorial decisions. This emboldened them to claim their rights before the state.

After the abolition of serfdom, the main issue moving the Czech countryside became that of statute labour. With the gradual emancipation of the peasant population statute labour was perceived increasingly negatively, and its rejection related not only to its increase in connection with the wars of the Austrian inheritance conducted by Maria Theresa, but also to the strengthening of the economic status and prestige of the village elites, which often perceived statute labour as a disgrace. A partial solution was brought about by reform proposed by the court counsellor František Antonín Raab (so called Raabization) of dividing estates of the nobility among the subjects, and the abolishment of serfdom, where only cash duties towards seigneurial lords would remain. Raabization was introduced in the crown estates from 1775 , but remained advisory to landlords, and a large part of the nobility stood against it [Černý 1928].

Joseph II wanted to address the issue of statute labour and the position of the peasantry within the framework of the subsequent "Taxation and Urbarial Decree", issued in 1789 
against resistance from the nobility, to be in force from 1790 practice. Rural society, which often referred to this decree as golden because it sought to precisely define the payment obligations of subjects to the state and the lords, waited impatiently. The idea of the golden decree removing feudal obligations had long endured among the rural population of Bohemia. It had been the source of the last peasant rebellion in Bohemia in the year 1775, amid the rumoured "golden letter" from the Emperor to abolish statute labour. This rumour about such a document, arising in 1771, spread to the East and Central Bohemia, with the sense that the nobility was obstructing such a decree.

\section{Enlightenment and Its Media}

The attitude of "enlighteners" differed in that it was above all utilitarian and rational, sometimes even panegyric. This was reflected in the thought of the so-called Enlightenment populists who, following the French physiocrats, stressed the importance of agriculture and saw population growth as a basic precondition for the welfare and power of the State [Kutnar 1948a: 23].

The influence of this world view on the nobility in the Czech lands was considerable. One nobleman, Count Franz Anton von Sporck (1662-1738), brought a whole range of new ideas and impulses to the world of Czech provincialism and his palace became a social centre where he influenced the views of his guests and in 1701 opened a theatre.

In the 40sthe movement of the Freemason's lodge (most probably through French soldiers involved in the campaign of French-Bavarian-Saxonian armies in support of the claims of the Bavarian Kurfürst Karl Albert to the Czech throne against Maria Theresia) arrived in the Czech lands [Beránek 1994: 96]. The most influential person of the Czech masonic movement was the Knight Ignaz von Born (1742-1791), who was also a leading organizer of scientific life. In the seventies von Born published the weekly Prague Scholarly News (Prager gelehrte Nachrichten) and was one of the founders of the Private Scholarly Society, which was later (1791) promoted by Leopold II. The Royal Czech Society of Sciences was the predecessor of the Academy of Sciences.

It is difficult to adequately reconstruct the views of the common people in the 18th century Czech lands. One source, however, is the memoirs of village mayor František Vavák (1741-1816). Other information from this time can be gathered from popular ballads which brought war news or tales about extraordinary events, and broadsheets.

Industrial leaders, who at the end of the 18th century still held attitudes not so distant from the feudal life-style, were too weak to influence political and cultural affairs to a large extent. The ideology of "the third estate" in the Czech Lands was marked by a combination of conservative Catholicism and moderate Enlightenment (G. Dobner, M. A. Voigt, F. F. Prochazka) [Bèlina 1985: 83].

The Age of Enlightement in the 18th century, especially in its second stage, was also influential on the development of Czech society, which at that time had been living for over two centuries within the multinational Habsburg monarchy. The impact of these ideas on Czech society was an important milestone in Czech history. The state reform policy during the so-called enlightement absolutism, which started in the Theresian period (1740-1780) during the reign of Maria Theresia, and continued into the Josephian period, started to loosen the foundations of society. During the period of Emperor Joseph II (1780-1790) the 
reformist actions of enlightened absolutism - characterized by strict centralism, enlightened church policy and economic reforms (ie. the abolition of serfdom) - reached its peak. However, this enlightened absolutism was at the same time in opposition to awakening Czech nationalist sentiments.

As the period of enlightenment began, the Czech nation was in a miserable state. This was the result of national political, social and cultural suppression, which had hit the Czech lands and its people in the period following the Battle at the White Mountain (1620). The reform of state administration carried out from the 1740s represented a further step towards the elimination of the remnants of the self-governing status of the Czech lands in favour of the rule of central authorities in Vienna.

From the 1770s the situation worsened as a result of a deliberate policy of germanization, implemented by the Habsburg state based on the centralist and bureaucratic principles of enlightened absolutism. The attempt to introduce German as the standard administrative language was at first made as a practical policy of the central state administration. The effort to proceed with the language unification of public life within the Habsburg monarchy, demonstrated a desire to unite its nationally heterogenous population into a single political state. In the Czech lands, this policy of germanization during the Theresian and Josephian periods encroached considerably on the state administration and practically all levels of education.

During the process of the formation of modern nation-states in Western Europe, certain state political factors (nations in this area being formed around centralized state power, and with a few exceptions ethnically or nationally homogenous) played an important role. In central, southeastern and eastern Europe the political factors were different. Over the course of centuries, several big states with largely ethnically heterogeneous populations had arisen. The formation of ethnic nation-states in this area lacked the support of the central state (in the case of some ethnic nations, including the Czechs, a case for independence could be made based on the traditions and remnants of previous independent political life). Unlike in Western Europe, the creation of states based on ethnically homogeneous populations threatened the central State, rather than strengthening it.

The Czech nation was constituted from within the multinational Habsburg state and was profoundly affected by the experience. The first stage of the Czech National Revival was mostly "linguistic" in character. It was a reversal of the deep decline of the Czech language after 1620 when a once cultured literary language degenerated into a mere means of communication among the common people. A small, but socially rather heterogeneous, section of educated members of the Czech ethnic community, became upholders of an awakening effort to revitalize national life. The language and literary revival began to crystallize at the beginning of the 1770s as a direct reaction to the germanization of education and government in the Czech lands.

Besides Czech literature during the late 18th century National Revival in the Czech lands, theatre made significant progress at this time. The busy and successful thespians of the Josephian period provided perhaps the most visible evidence of the emerging national emancipation efforts.

Theatre was nothing new in Prague at this time. In fact, Prague already had a reputation as a theatre town. From 1738 Prague theatre had had a permanent staging area in the so-called "V Kotcích", where different theatre groups performed comedies, dramas 
and Italian opera. But these performances were of no special importance to the origin of Czech revival theatre. Until the 1780s, Prague lacked a cultured audience to which Czech plays could be introduced. The cultural life of noble, urban and educated circles was largely germanised. The language of plays in Prague's theatres was German, with Italian used for operas.

During the first half of 1785 several Czech performances were held on the stage of the new Nostic Theatre of the Estates. These performances were an overnight sensation, which helped launch a Czech-language theatre. As no Prague building was available for this purpose, a new wooden theatre was constructed at the Horse Square, which was later called "Bouda" (The Shack). The leading organizer of the Czech theatre at that time was Václav Thám (1765 - approx. 1816).

For the patriotic effort of the Czech revival, the theatre was tremendously important. Theatre entertainment was the best way to gather and unite a heterogeneous, but nevertheless Czech-speaking, community of people. A big advantage of theatre was that it did not demand literacy or previous education from its audience. In fact, there were no problems finding an audience, as theatre was one of the most popular forms of entertainment for all levels of society. Not only at the beginning, but throughout the whole period of the national revival, theatre was perhaps the most important instrument of mass communication.

Through the Czech theatre, the awakening intelligensia could convey the ideas of the national emancipation movement to the general public. The Czech performances at the "Bouda" were not only sought after by the inhabitants of Prague, but attended by people from the countryside. The viability of Czech theatre in the Josephian period was proved among other things by the fact that in the first one and a half years after it was launched the Bouda introduced about 130 performances in Czech [Černý 1969: 43].

Also important in the formation of the public sphere were printed periodicals. Although the printing press was invented in the mid-15th century, print culture didn't spread until later, mostly in the 18th century. The degree of participation it enabled contrasted with the older model of political action that grew up in the royal courts, among the elites, and occurred in secrecy. The emerging public, on the other hand, was strongly shaped through the press, among which newspapers were important, although there were other types of publication. Eisenstein [2005] suggests that printing and print culture should be considered an implicit public sphere. She argues that the wide adoption of print technology revolutionized the status of the public and the organization of knowledge, and thus the potential for the democratic institutions of liberal society. Print had the power to influence social change and played a major role in the emergence of Enlightenment ideas. It is obvious that in the late 18th century even the Austrian bureaucracy realized this fact [NA, f. PČG, k. 244, fasc. 15e/774].

The history of the Czech press until the middle of the 1780 s was very bleak. The first Czech-language newspaper was published in Prague in 1719 by an educated, national revivalist owner of a printing shop, Karel František Rosenmüller. The paper appeared twice a week, on Tuesdays and Saturdays, giving it its name "Sobotní (Outerní) Pražské Poštovské Noviny z Rozličných Zemí Přicházející a Obzvláštním Jeho Císařské a Královské Milosti Nadáním Obdarované" (Saturday (Tuesday) Prague Postal News from Different Countries as a Grant of Exceptional Imperial and Royal Mercy). 
In content, this newspaper represented a collection of news items which their publisher took from different sources (mainly Vienna papers), and mechanically arranged without regard to importance. It lacked both the evaluation of events and original commentary.

From its beginning the newspaper struggled with a number of obstacles, the most serious of which was a lack of permanent subscribers. Although it seems that in Rosenmüller's lifetime the newspaper had at least enough subscribers to make a profit and to cover printing costs, after Rosenmüller died his heirs encountered problems. The content and quality of the newspaper declined, and it started to lose subscribers, so that in 1772 after 53 years of existence, the newspaper closed down. For ten years the Czech public had to make do without their own newspaper, while a small group of more educated Czechs followed the German-language press.

In 1782 (during a period of a more liberal press conditions and limited censorship) the new Pražské České Noviny (Prague Czech News), edited by František Kozury, started in one of Rosenmüller's former printshops. From 1785 the newspaper was published under the name Schönfeldovské cís. král. Pražské Poštovské Noviny (Schönfeld's Imperial and Royal Prague Postal News) by a leading Prague and Vienna printer and publisher Jan Ferdinand, The Knight of Schönfeld (who also published a German paper, K. K. Prager Oberpostamts Zeitung) [Volf 1935, 412]. During the Josephian period, a time of great change, the public became increasing interested in current political events and public affairs. At the demand of Schönfeld, Kozury was replaced as editor in 1786 by Matěj Václav Kramerius (1753-1808), who is credited as the founder of modern Czech journalism.

In Kramerius' time, an editor's work was in many respects different from the work of an editor today. The editorial office did not comprise a group of journalists and reporters who would gather news and take charge of the contents of individual sections; it was the editor who was responsible for the content of the whole newspaper. They themselves had to gather news from different sources, edit it, and possibly add some commentary (at this time not a common practice). Furthermore, they usually ensured the setting and printing of the newspapers. But even this was not all: the duties of an editor usually included the acquisition of subscribers and customers, quite often the circulation of newspapers and the sale of individual issues.

When Kramerius took over the editorial office of Schönfeld's newspaper he had almost nothing to build on in terms of local Czech journalistic work. He followed the model of the then leading German journals published in Austria and Germany. The readers were informed first of all about the numerous Imperial orders and circulars (published mostly in full Czech translation). Then followed a variety of news divided into special sections, followed by regular features. From time to time there was also economic news and essays on economic themes. The last part of the newspaper contained the announcement of different sales, purchases, auctions, and sometimes cultural features, mostly on new Czech books and theatre performances. Sometimes Kramerius printed reader's letters as well (later on he began to form a network of regular correspondents). Individual reports did not yet have special headlines; the use of these started later.

Schönfeld's Imperial and Royal Prague Postal News was published under Kramerius' editorship once a week on Fridays and distributed to the countryside by Saturday post. A typical issue was of half-sheet size and usually had 8 pages. A subscription could be had for four gold sovereigns a year. When, at the beginning of 1786, Kramerius assumed his 
position in Schönfeld's newspaper, it had fewer than a hundred permament subscribers. Towards the end of his period in Schönfeld's service there were 900 [Herben 1926: 32]. In 1789, Kramerius, after disputes with Schönfeld, left the paper and started to print his own newspaper, Kraméryusowy Cýsařské král. Wlasteneské Nowiny (Kramerius' Imperial and Royal Patriotic News) which he successfully ran (it is said that in some periods it had as many as 1400 customers) until his death [Volf 1935: 415].

At the beginning of $1790 \mathrm{M}$. V. Kramerius announced the launch of the Publishing and Bookseller's firm Česká expedice (The Czech Expedition). The beginnings of the Czech Expedition were rather modest. Apart from publishing and selling Czech papers, Kramerius provided interested persons in Prague and the countryside population with highly prized books, arranging the exchange of books among readers and other small booksellers. In 1791 (after he married advantageously), Kramerius extended his firm and later enlarged it to include a printing shop. He sold not only new (almost exclusively Czech) books, but also had a large second-hand bookshop. He published informative, educational, and light reading. While in other Prague publishing houses books appeared with some exceptions in editions of less than a hundred copies, Kramerius published individual books from the beginning mostly in much greater numbers (in the case of successful books the edition was around 600 copies) [Novotny 1973: 221]. Thanks to Kramerius' initiative, by the end of the 18 th century the foundations of modern Czech journalism, literature and public opinion had been established.

The contents of Kramerius' newspaper were influenced, shortly after it entered circulation, by radical political events in France. The first news of the uprising of the Parisian people and disturbances in France appeared in this newspaper quite promptly, on the 1st August 1789. Soon after this, news of the revolutionary uprising of the Parisians spread throughout Europe, in the second part of July 1789, and anxiety became evident at the court in Vienna and among representatives of the state apparatus of the Habsburg Empire. There were worries that such events could have an undesirable effect on the behaviour of the population and could endanger peace and order. The Austrian authorities followed the situation and atmosphere among the people in Bohemia with great attention. They regarded Czech serfs as potential rebels and therefore worried that the events of the Country Rebellion of 1775, which was still remembered by many Czechs, could be repeated [Kutnar 1948a].

Although Joseph II tried for a time to continue with his courageous reform policy, events in France aroused serious apprehension. From the middle of August 1789 printing news from revolutionary France was forbidden. This ban lasted until the middle of 1790 [Haubelt 1989: 24]. Even later, newspapers were still not allowed to write about people's movements in the French countryside, or to publicise measures declared by the French Constituent Assembly in favour of civil rights and social equality.

\section{Echoes of a Great Rebellion: The First “Inquiries” into the Mood and Sentiments of the Population in the Czech Lands, and Their Context}

The French Revolution can be regarded as one of the key world events impacting the Czech lands at the birth of what can be called public opinion [Madl - Tinková 2012: 13]. The outbreak of the revolution in France in the year 1789, and the measures taken by 
the Revolutionary National Assembly, upended the nobility, also provoked the unrest in the Austrian (Bohemian) environment. Although slow compared with today's ideas, news spread quite quickly for society at that time. The basic source of information was often waggoners, long haul carriers who brought tales of what they heard in inns in foreign cities. It was also common to visit nearby markets where vendors also had "guaranteed" reports, which often also served as part of the sales promotion for certain goods.

By loosening censorship (the preliminary abolition of censorship), Josef II made space for the generation of public opinion. He created a capacity for dialogue where everybody could form their own opinion on the basis of available information, which the state only helped to supplement. However, with regard to the changing situation, it became apparent that this carried risks and required changing. The plurality of public opinion was no longer desirable, as the state needed public opinion to stand behind its steps and in no way wished to permit the French example to be followed. In creating public opinion, thus allowing access to information, the state distinguished between social classes and also nationality (the especially languages). The re-introduced censorship affected Czech texts more than German ones. The urban environment, dominated by the German language, had at its disposal a wider range of news than the Czech countryside [Madl 2012: 33-37].

The biggest concern was that the ideals of the French Revolution could be caught by a rebellious peasantry [Tinková 2012: 102]. Altogether the government in Vienna clearly considered the Czech peasants more open to revolutionary ideas than the Germanones. The defiant Czech peasant was always pleased if he could outsmart or deceive the nobility [NA, f. ČG-P, fasc. 115/329]. However, this argumentation, substantiated by a series of peasant uprisings (from 1680 to 1775), increasingly moved into the ideological plane. There were evident efforts to prove that the Czech peasant thought differently and more dangerously regarding the state and its order. To support these conclusions, arguments from the history of the reformation were used, when the Czech society at first apparently became addicted to Hussitism, and subsequently, with the overwhelming majority, claimed allegiance to the reformation. Religious freedom in the Czech environment was taken to an unprecedented extent and covered all classes of society in the early modern period. The concern was that the Czech peasant would understand "liberty in corporeality" as they once understood "freedom in religion", which meant too broadly and in a way destructive of the conventional order, which would lead only to breakdown [NA, f. ČG-P, k. 2368, fasc. 115/340].

The start of the 1890s was marked by the expurgation of reports from the French environment. In order that the Czech peasant should not imitate the French "rebellion", information about it had to be concealed [NA, f. ČG-P, k. 2367, fasc. 115/301]. On the basis of the Decree of the Bohemian Gubernia of 28 February 1790, access to and residence in Bohemia was tightened for Frenchmen. People coming from France "should be held either in the capital of Prague or in Vienna" [NA,f. PČG, k. 252, Nařizení královského českého gubernium, 28. 2. 1790f]. These measures, however, appeared ineffective. The lack of official information was, certainly, replaced by oral dissemination. From surviving reports, it is clear that the ideas of liberty and equality found a response among the people, and these issues were subject to lively discussion. By a court decree dated November 30, 1792, oral or written dissemination of suspicious reports, brochures or leaflets was forbidden, with the threat of severe punishments [Kutnar 1937: 338]. The decree was formulated very broadly to affect the widest range of actions, including, for example, book lending. 
From 1793, there was an observable change of policy that, in addition to the censorship of incoming reports, amounted to the active formation of public opinion. On the basis of the decree of the Czech Governor of March 1, 1793, the clergy were ordered to preach to the masses about the unlawfulness, chaos, disruption, moral decline, and great poverty, of French rural areas [NA, f. PČG, $k .243$, fasc. 15e/270]. Reports from revolutionary France were no longer concealed, but were adjusted so that their implication was negative, freeing them of their attractive force and fomenting fear of the disastrous consequences of the French Revolution [NA, f. PČG, $k .255$, fasc. 16/1]. Public opinion could thus be pacified and made loyal to Vienna. The beginning of these efforts was a brief pamphlet entitled "Unfortunate French Stories and more than Cruel Murders", produced by a "a certain patriot" in the year 1793, but more likely a state commission. Posing as an eyewitness, he points to the disorder, rampancy and cruelty of the new orders, emphasizing that "only where confidence and love for God, religion and safety of the monarch reign do happiness and peace of man reside" [NA, f. Č G-P, k. 2367, fasc. 115/301]. In a similar spirit there two two pamphlets written in German Menschenrechte diesseits und jenseits des Rheines ein Wort zur Beherziehung und Anrede eines alten österreichisches Feldkapettans an seine wackeren Kriegskameraden auf dem Marsch gegen Frankreich (Human rights on both sides of the Rhine: a word of greeting and address of an old Austrian field captain to his brave war comrades on the march against France; 1792) [NA, f. PČG, k. 255, fasc. 16/290]. It was not an isolated attempt. Even the literacy of the Czech rural area, and, to a certain extent, faith in the written word, were enlisted in the cause. In 1793 a book by Aleš Pařík, Head of a Prague primary school, was entitled "On Freedom and Urban Equality, what is it and what arises from it among the Frenchmen, to all dear patriots of the Czech nation, to instruct and even warn" [NA, f. ČG-P, k. 2368, fasc 115/340]. The Czech edition of this book triggered a discussion about whether to use the words liberty and equality as the basic concepts of the French Revolution. The view prevailed that these concepts could be used with caution, but with modified meaning, so as not to cause inappropriate expectations. In a similar spirit came (1797) a book from František Vavák, village mayor of Central Bohemian Milcice, Dark in the Day as in the Night in the Reason of Man.

In the forming of public opinion, special significance has generally been accorded to the press. In addition to various pamphlets, there were also newspapers. In Prague, however, the publications of Kramerius' patriotic newspaper based in Prague did not meet the expectations of Vienna, even while avoiding reports covering the French environment and in favour of other events (e.g. wars with the Turks). By a Decree of November 30, 1792, it was forbidden to publish articles from foreign newspapers [NA, f. PČG, $k$. 255, fasc. 16/1]. The Czech Governorship in early 1794 even considered the idea of itself publishing the "Volkszeitung" in the Czech language, informing the public about events in accordance with the attitude of the Viennese government [NA, f. PČG, k. 244, fasc. 15e/774].

For the urban environment, the authoritative reports were in German and partly in French. The censors did not impinge upon German books and newspapers with the same force, as they did the Czech press. At the same time, there also arose the possibility of importing foreign press, banned until the Gubernial Decree of April 8, 1793 [NA, f. ČG-P, k. 2367, fasc. 115/303]. Middle-class people, who were more open to the ideals of the French Revolution, were monitored in the public environment. If someone was given the name "Jacobin", standing for those who conceived of change according to the French 
model, it could have a very negative effect on their position in society or in the sphere of work [NA, f. PČ,$k .79]$. It therefore became necessary to beware certain topics of conversation, and consider the persons with whom talk was conducted, because the number of secret police had increased.

\section{Reports of Governors about the Mood of the Population in Their Regions}

The French Revolution can be regarded as one of the key world events, and in the Czech lands it lay at the root of what might be called public opinion [Madl - Tinková 2012: 13]. After the outbreak of the revolution the Czech authorities (Czech Gubernium) were asked to provide detailed information about the expansion of Czech newspapers and about the influence of information about events in France disseminated among the rural Czech population [Novotny 1973: 105]. The authorities were especially concerned about the fact that, according to several reports, Czech peasants supposedly devoured such details [Ibid.: 104], and at the request of the Czech-Austrian offices they attempted to find out through local governors the mood of the people in the country. Leopold himself, via a decree of December 12, 1791 ordered the heads of provincial governments to track the mood of the population [Kutnar 1937: 325], to prevent discontent, internal unrest, and revolutionary moods among the population.

In 1793 local governors were asked about the mood of the population in their regions. The governor of Chrudim [NA, f. 1126, sign. 165/4, ca 3343], for example, replied that Czech newspapers were spreading a dangerous mood, and also complained that newspapers were received by almost all priests in the region, who could then lend them to peasants. The governor suggested that newspapers should depict the events in France in the blackest colors to encourage their audience to obedience and love of calm times [Roubik 1923: 177]. Generally, the governors complained that the peasants were able to participate in debate about liberal ideas, serfdom and revolution. Additionally, they criticized newspapers because they were read by even the lowest classes, and highlighted the dangers of the influence of newspapers on the mood of the population. The governor of Litomyšl complained that the serfs were prone to revolutionary ideas, talked about the equality of all strata of the population, and, moreover, reflected on their views loudly even in the presence of officials [Ibid.: 176]. Similar complaints about the views of the public came from other regions of the country [see: Ibid.: 177]. The newspapers had to be consistently censored so that no columns included ambiguous information. Special emphasis was placed on reports from abroad from which defective ideas had been removed. Readers were accustomed to receiving such reports, and discussed the possible reasons for such omissions [NA, f. PČG, k. 255, fasc. 16/264].

Police Minister Pergen himself warned the High Sheriff (burgrave) of Prague that there were reports of riots and the excesses of freedom-obsessed mobs, and that these ideas of freedom and equality were not only not criticised by newspapers, but even sometimes secretly approved. Pergen thus demanded strict censorship ${ }^{1}$ [Novotný 1973: 109]. It was at

\footnotetext{
1 This strong censorship can be later seen in all aspects of everyday life. For example there was a decree ordering all manuscripts prepared for letterpress publishing to be submitted for censors' approval $[N A, f .188$, sign. 1543, ca 20].
} 
his behest in 1794 that additional research was conducted on the mood of the people. This research found a considerable influence on public opinion from contact with returning soldiers, and that moods were also affected by dissatisfaction with low wages, high taxes, war, or the general increase of prices of basicgoods. Moreover, people looked forward to the arrival of the French, who allegedly "wrestled with their masters after their pattern" [Ibid.: 126]. The Czech Governorship too was aware of the influence of those who had seen the situation in France with their own eyes. People coming from France were to be placed under specialmonitoring. The theme of eyewitness (solders') accounts, of course, formed the content of official brochures, through which the authorities hoped to form the public opinion [NA, f. PČG, k. 255, fasc. 16/290].

The authorities were increasingly worried about the influence of revolutionary propaganda,_at a time when French revolutionary armies were heading eastwards. They closely monitored every social movement of the peasants, and every qualm led to widespread investigation. For example, in autumn 1792 in Moravia it was found that a mysterious hunter had spread information about events on the French lines in the countryside among the people there [Mejdrická 1959: 86]. At that time the slightest evidence that someone somewhere was talking about the war, against the Habsburg war effort or about France, was sufficient to have them placed under police surveillance. State supervision was a precautionary measure against individuals who had the ability to spread dangerous ideas [Kutnar 1937: 334]. Much trouble with the police involved those expressing opinions about the causes of the revolution, ie. the French nobility oppressing the serfs, as was the perception in the Czech lands. Such statements in the period in question were superabundant [see: Mejdřická 1959: 88]. For example, the son of an innkeeper in Prague claimed that in Prague there was a group called Friends of the Constitution and that he was a staunch supporter. In 1792 in Prague a leaflet was found calling for an armed uprising to fight for freedom [Ibid.: 86]. In 1793, when the French revolution culminated, police commonly received reports that the people were demanding their rights. In the Litomyšl region there were complaints from its inhabitants against injustice, arguing that even in Bohemia what was happening in France could be repeated [Kutnar 1948a: 68]. Litomyšl's guvernor proposed severe punishment for these troublemakers, but was vetoed by superiors who suggested milder treatment, taking the view that misguided popular misconceptions needed to be argued against rather than suppressed [Mejdřická 1959: 87].

As a source of information on public opinion the chronicle of František Vavák [1907-1938 (1770-1816)] is valuable. From this it is obvious that people were thinking and arguing about revolution. Vavák writes that he had heard villagers talking about how they felt about the revolution and its causes. As a chronicler from Milcice in Central Bohemia, he repeatedly recorded that the news of the French Revolution had spread among the people. As a loyal subject, he spoke of these stories as despicable fables. Some found reasons for the revolution in the fact that the French people despised the king and queen for their lavish lifestyle, while others argued that the cause lay in unbearable serfdom. According to others the trigger was a queen who spent too much and provoked the king against the regions and Parliament [Kutnar 1948a: 123]. From Vavák's chronicles it can be concluded that the people, although the official newspaper brought censored counter-revolutionary information (complemented by the local priest's sermon), had information 
from elsewhere, and that the reasons for the revolution and current events were judged according to their own experience.

Reports from the Čáslav, Kouřim, Hradec and Boleslav regions [NA, f. 1126, sign. 165/1, ca 3340; sign. 165/2, ca 3341; sign. 165/5, ca 3344; sign. 165/6, ca 3345] in spring 1793 accused peasants of fomenting ideas about freedom, and being in favour of French ideas. In addition, the population anticipated the arrival of French freedom and the abolition of serfdom. The authorities still insisted that stringent bans on the spread of opinion were not appropriate because they would only irritate people and the Czech authorities (Czech Gubernium) should not display such conspicuous concern about the loyalty of their people [NA, f. ČG-P, k. 2368, fasc. 115/340]. Some accounts showed that the people were scared of a revolutionary war and reported strong disagreement with it. The governor of Žatec [NA, f. 1126, sign. 165/12, ca 3353] feared the mentality of the poorer classes, who had nothing to lose and, lacking their own economic resources, could turn dangerous. News about the French and their fight for freedom was spreading through invalided soldiers or exchanged prisoners. General dissatisfaction spread concerning the revival of levies and war taxes. In Budějovice and Čáslav regions [NA, f. 1126, sign. 165/5, ca 3344; sign. 165/8, ca 3348] there were reports of people directly referring to the French example and refusing to pay their serfdom fees, which heightened the concerns of the nobility that the poor would rise up against them. The governors of Kouřim and Beroun [NA, f. 1126, sign. 165/6, ca 3345; sign. 165/16, ca 3358, 3359] criticized the newspapers, which, despite censorship, informed the peasants about Austrian military failures. The people's discontent had, however, economic and social causes, and thus was closely monitored for the slightest alteration that could transform discontent into action.

On the Vysoké Mýto estate people murmured against serfdom and on the market vowed that their offspring would not go to war come what may [Mejdrická 1959: 102]. The governor of Prácheň [NA, f. 1126, sign. 165/9, ca 3349] wrote that the establishment of the militia made people sense the danger of an enemy attack and, as a consequence, the peasants were reluctant to move away from their own property. There was talk that the French were freeing serfs from serfdom. A similar opinion was held by the governor of Tábor [NA, f. 1126, sign. 165/7, ca 3346, 3347], who wrote that the mentality of the population was such that above all it wanted peace.

The nobility tried to reduce the risk of the spread of revolutionary ideas by having the authorities draft legislation to control the countryside. For each village pub a printed regulation was issued where the landlord was commanded not to suffer free speech. Village pubs were also forbidden to subscribe to a newspaper [Mejdrická 1959: 161]. The Czech authorities (Czech Gubernium) later also forbade reading rooms [NA, f. 188, sign. 1825, ca 23] and banned reading - except for permitted newspapers - in coffee houses and other public spaces [NA, f. 188, sign. 1831, ca 23].

In 1795 an order was issued for treason against all who threatened order, which was deemed to include even not reporting subversive activity. The order decreed punishment for disturbing the public peace, e.g. through public speeches which gave rise to dissatisfaction with the state system. Offenses included participating in secret societies, publishing unannounced, and the sale and dissemination of banned books [NA, f. 188, sign. 1674, ca 21; sign. 1821, ca 23; Mejdřická 1959: 162]. 


\section{Folk Legends}

Important sources of popular opinion were rumours, legends and prophetic pronouncements. These often made criticisms of the social order, and expressed a desire for a better and fairer world. One example was rumours of the death of Emperor Joseph II. The people did not want to believe stories of his death and associated his return with the emancipatory arrival of the French [Vavák, book 2, part 2: 149, 150]. Rumours that he had been killed by his enemies were rejected [Novotný 1973: 111; Vavák, book 2, part 2: 151]. Propheric pronouncements from this time also reflected the hope that "when the French come here ... true freedom will be created, and all the spiritual and secular nobility ruined and banished" [Vavák, book 3, part 1: 85]. Other aspirations were voiced concerning the active participation of the peasant people, who, after the arrival of the French troops, would seize the moment and make themselves free. In the evangelical environment there appeared the additional motif of full religious freedom and victory over Catholicism [Kutnar 1948a: 67].

Contemporary rumors also had a national-political aspect. They asserted that under French influence an independent Czech state would be formed. The French would apparently return the Czech crown to Prague and give the Czechs a new king. This social and political vision of a better future was the fruit of popular social and political utopianism.

Prophetic pronouncements, legends and folk songs proliferated, and their disseminators were found mainly in low-income sprohrata [Mejdřická 1959: 84]. The poor had yearned for a just social order in which everyone was equal. Now prophetic visions, arising from existential needs, were the focus for hopes founded on the current intellectual and political situation. "What attracted both learned and unlearned to such prophetic pronouncement, was its apparent affirmation in a political and social situation that interested individuals regardless of their legal and practical exclusion from public events and inability to influence them" [Kutnar 1946: 135]. Such public pronouncements viewed people were not just as masses, as participants who felt politically and socially equal [Ibid.]. The reason so many simple men clung to popular prophetic pronouncements was that society had no other way to publicly express its views [Ibid.: 138]. In this context, we can understand them as a reflection of popular opinion [Ibid.], as the collective property of a certain social environment [Kutnar 1948a: 124]. They had an important function for socio-political tension as an inner valve for folk-thinking, expressing the social, political and religious ideas, hopes and aspirations of the people, and becoming a consolation for the oppressed.

Times of war, peasant mutinies and revolutionary restlessness, had caused the people to turn to folk prophecies. They believed these alongside socio-political rumors, and gave them increasing credence. People also strained toward to the future, reflecting on unspoken desires and needs.

Prophetic pronouncement acted as a kind of promotional publicist, expressing what the people thought about events, but also what they believed in and regarded as a social vision. 


\section{Leaflets and Brochures}

As well as the danger of word of mouth, the Prague authorities considered publications, and on 24 June 1791 pointed out the danger of pamphlets discussing state matters. Considering these outrageous, they demanded their censorship, so that nothing should foment discontent among the people [NA, f. ČG-P, k. 2362, fasc. 115/210]; as, for example, concerning the prices of necessities, which were a popular topic in cafes and pubs [Kutnar 1937: 325].

An important example is the leaflet Manifesto of the secret National Convention of Josephine's liberal Czechs. This leaflet, written in German in January 1793, was found on a road near Chomutov and compared the work of Joseph II with the enlightened activities of the French nation. French peasants had proven that it was possible to fight for their rights with their own strength. The leaflet challenged the Czechs to follow them. Another leaflet was found near Karlovy Vary, and revelled in rebellion. The nobility in such cases commanded their operatives to determine the circulation of such leaflets, and how they were affecting the mood of the population.

The opinion of the peasantry was actively affected by schools, the press, sermons and counter-revolutionary pamphlets, which all lectured the common people about the dread of revolution, and of its depravity both economic and social. Such leaflets and pamphlets depicted the misery of peasants in France, claiming that the rebellion was not by the choice and demand of French serfs, but because they were seduced by political demagogues [Kutnar 1948a: 66]. Prior to the publication of any printed matter, consent had to be ensured and content determined 'safe' [NA, f. ČG-P, k. 2362, fasc. 115/212].

The authorities used various literary devices to influence popular opinion. Thus, for example, they published a pamphlet against the spirit of the revolution, as well as other minor publications and promotional pamphlets to influence public opinion. Most anti-revolutionary pamphlets based in the Czech lands were translations of German ones, or imitations of them. Targeted propaganda pamphlets could be divided into several types, and there were those that were intended purely for ordinary people, the peasants. These were in Czech and German, and their aim was to highlight the good position of peasants in the Czech lands and remind them of their obligations to the sovereign and the nobility. Writings in praise of peasant status, which emphasized the importance of peasants, were propagandistic, to distract the peasants from the revolutionary struggle. Generally, State booklets and leaflets presented revolution as riding roughshod over public policy. Often, booklet-style sermons were published that emphasized Christian duty and honor to God in contrast to the French heathens, where the revolution was presented as a work of the devil [Tinková 2012: 105].

There were also several anti-revolutionary tracts, while a defence of the state was embedded in anti-revolutionary sermons. Thus, the state was trying to influence the thinking of serfs in a systematic and organized way. Local authorities were sent various pamphlets to be handed out to civilians and soldiers. These leaflets were rousing, anti-French pamphlets, celebrating the armies of the Austrian Empire. The authorities also wanted to create a counterweight to Kramerius' popular newspapers which, despite censorship, did not fulfil adequately the promotional task required, so in Vienna it was deemed necessary to issue Czech people with newspapers to promote and disseminate an anti-revolutionary mood [Mejdřická 1959: 164]. 
Forbidden fruit, however, had an enticing taste. Although anonymous and unauthorised printing was punished, clandestine leaflets and anonymous tracts were still printed and widely circulated. Punishment was also threatened for those who spread revolutionary ideas by word of mouth in the spirit of revolution and freedom [Kutnar 1937: 339].

\section{Newspapers}

Due to the concerns of the nobility about revolutionary ideas, censorship of newspapers and reports reprinted from foreign newspapers and sources was introduced early on. Every movement was monitored and anti-government rebels were to be prosecuted. Regional authorities had to send monthly reports to the High Sheriff (burgrave) informing him about events in their localities. The authorities stressed the need to prevent the spread of French ideas and the influence of dangerous troublemakers. "Reliable citizens" were commissioned to help counter the effects of revolutionary propaganda and oversee the banning of publications, listening out for dissent [Mejdrická 1959: 160].

It was paramount that the ideas of the French Revolution should not get to ordinary people. Foreign newspapers were considered dangerous disseminators of dangerous ideas, which pointed to the necessity of censorship. A decree of 11 March 1792 ordered the strict censorship of foreign newspapers because they could widen the "dangerous opinion" that would undermine public peace [NA, f. PČG, $k$. 256, fasc 16/2009]. Nothing should be published that tempted people to delusions [Kutnar 1937: 326]. The population should not be encouraged to curiosity, seduced to sins; truth and reality should not be presented directly. So, although the newspaper apparently did not affect the reader's judgment, it formed part of a clear psychological game of public authority with the people. Above all, revolutionary ideas should not reach the lowest strata; there were particular fears about revolutionary ideas among the peasants [Kutnar 1937: 327]. Counterrevolutionary newspapers therefore should present the pernicious consequences of revolution in a popular and easily understandable style [NA, f. PČG, k. 244, fasc. 15e/774].

A significant role in disseminating information about the situation in France among Czech people was played by Kramerius' newspapers [Novotný 1973: 127; Kramerius 1790-]. Although they were censored, through them readers learned about the key events and actions, and informed their general views. A more dramatic sense of revolutionary transformation was provided by forms of political prophecy (as mentioned above) [Novotný 1973: 128].

\section{Conclusion}

In this study we have dealt with the issue of mass communication and public opinion in the Czech lands in the 18th century. This brought into focus a socio-political situation in which the emerging Czech national revival gained traction. The climate of this period was shaped by the constant influence of the Catholic church, but saw a number of new phenomena, such as intellectual discussion in aristocratic salons, the emergence of the first scientific societies, the diffusion of foreign ideas and propaganda, the beginnings of Czech printed newspapers and theatres, and finally opinion streams collectively emerging from the folk environment. Specifically, the spotlight falls on the moment when Bohemia 
began to receive reports about the French revolution. These reports raised concerns in the Vienna court: triggering the spread of rumours and legends among the ordinary people and leading to control of the press (censorship), and alongside this official surveys of the mood and sentiments of the population. This was the time when the Czech lands began to give birth to modern public opinion.

According to Lee Benson [1967-1968: 525] the study of public opinion in the historical perspective is associated with the use of gathering procedures and data sources which the researcher finds and sorts but does not create. Benson's [Ibid.: 532] study of public opinion in the historical perspective distinguishes three fundamental dimensions: the dissemination of opinion, the shaping of opinion, and its influence on the decisions of the ruling class. Following this approach we have tried to capture an image of public opinion with regard to all three dimensions in the Czech lands at the end of the 18th century, especially in the context of the popular opinion of the people concerning the ideas of the French revolution.

With Miroslav Svoboda [2012: 237] we should note that although reactions to the French revolution in the Czech environment are captured in several works [see Kutnar 1937, 1946, 1948a, 1948b; Roubík 1923; Mejdřická 1959], all of these works stem from documents of an official nature, which reported to the Habsburg monarchy the potentially dangerous acceptance of revolutionary ideas. These were mainly provided by the Czech authorities. The problem for the analyst lies in the fact that such sources may not have reflected the authentic attitude of the vast majority of rural people. A second problem might be that the state authorities were more interested in educated persons who had the potential to take on the revolutionary ideas and develop them. Indeed, Miroslav Hroch [1990: 192] notes that, in the late 18th century, the vast majority of the rural population was unable to comprehend concepts such as freedom, equality and civil rights. In folk chronicles such themes and concepts are absent, while common people are shown primarily concerned with the harvest and their own livelihoods.

Despite these limitations, the research of mass communications and public opinion during the 18th century has value. It shows the "moles" digging into pre-modern society, which later developed extensively during the 19th century, and beyond into modernity. Public opinion emerged as an important factor in social power, which could influence large groups of the population. This was frequently interwoven with what today is understood as "rumour" (fama), which means information of a non-official character, spread by word of mouth. At the same time there were interventions on both sides of the controversies of the day from the printed media- on the one hand, journalism arising from the people, and on the other, handed down by the authorities. It is also worth noting that the philosophical conceptions born in the 18th and early 19th centuries were mostly of a "monistic" character, ie. that they considered public opinion as united, while our analysis shows that a pluralistic opinion existed even at that time, in which the individual parts of the population could tend to have a more or less different view of the ongoing processes. Another characteristic of the age was the initial reflection on public opinion, a precursor of later public opinion research. This was undertaken not by independent analysts but by police agents, and their conclusions were considered secret information and not for public consumption. All the tendencies seen in this early phase of public opinion analysis were to continue through the subsequent centuries, and we can see echoes of them in our own era. 


\section{Bibliography}

\section{Archive materials ${ }^{2}$}

Národní archiv, České gubernium - Publicum (National Archive, Czech Gubernium - Publicum), fund 1126 - Průvodní listy zasílaných zasedacích protokolů krajských úřadů ke guberniu (Cover notes of regions' governors to Czech Gubernium)

Sign. 165/1, ca 3340 Boleslavsko (Boleslav region)

Sign. 165/2, ca 3341 Hradecko (Hradec region)

Sign. 165/4, ca 3343 Chrudimsko (Chrudim region)

Sign. 165/5, ca 3344 Čáslavsko (Čáslav region)

Sign. 165/6, ca 3345 Kouřimsko (Kouřim region)

Sign. 165/7, ca 3346, 3347 Táborsko (Tábor region)

Sign. 165/8, ca 3348 Budějovicko (Budějovice region)

Sign. 165/9, ca 3349 Prácheňsko (Prácheň region)

Sign. 165/12, ca 3353 Žatecko (Žatec region)

Sign. 165/16, ca 3358, 3359 Berounsko (Beroun region)

Národní archiv (National Archive), fund 188 - Cirkuláře a vyhlášky (Edictes and Decrees)

sign. 1543, ca 20 Nařízení gubernia odevzdávat nákresy k rytinám před vytisknutím ke schválení cenzuře (23rd of March, 1793) - The Decree of the Gubernium commit to censorship to approving blueprints of engraving before printing

sign. 1674, ca 21 Nařízení gubernia o všeobecném předpisu v cenzurních záležitostech (15th of May, 1795)

- The Decree of the Gubernium about general rule in censhorship

sign. 1821, ca 23 Nařízení gubernia o pokutách za obcházení cenzury vydavateli knih (9th of July, 1798) -

The Decree of the Gubernium about fees for evading censorship by publishers

sign. 1825, ca 23 Nařízení gubernia o zákazu čítáren (11th of August, 1798) - The Decree of the Gubernium about prohibition of reading houses

sign. 1831, ca 23 Nařízení gubernia o zákazu předkládat v kavárnách a jiných veřejních místnostech jiné než povolené noviny (23rd of September, 1798) - The Decree of the Gubernium about prohibition offering another newspapers then allowe by state in coffeehouses and public spaces

\section{Secondary bibliography}

Bauer, Wilhelm [1930]. Die Öffentliche Meinung in der Weltgeschichte. Wildpark-Potsdam: Akademische Verlagsgesellschaft Athenaion.

Bauer, Wilhelm [1934]. Public Opinion. Pp. 669-674 in Encyclopaedia of the Social Sciences. Vol. 12. New York: The Macmillan Company.

Bělina, Pavel [1985]. Česká města v 18. století a osvícenské reformy. Prague: Academia.

Beránek, Jiři [1994]. Tajemství lóži: Svobodné zednářství bez legend a mýtů. Prague: Mladá fronta.

Benson, Lee [1967-1968]. The Public Opinion Quarterly 31 (4), pp. 522-567.

Černý, František (ed.) [1969]. Dějiny českého divadla II. Národní obrození. Prague: Academia.

Eisenstein, Elizabeth [2005]. The Printing Revolution in Early Modern Europe. Cambridge: Cambridge University Press.

Habermas, Jurgen [2000]. Strukturální preměna veřejnosti. Prague: Filosofia.

Haubelt, Josef [1986]. České osvícenství. Prague: Svoboda.

Haubelt, Josef [1989]. Velká revoluce ve Francii a společnost v Českých zemích. Prague: Horizont.

Herben, Jan [1926]. Matěj Václav Kramerius - osvícený novináŕ a buditel. Prague: Volná myšlenka československá.

Hroch, Miroslav - Kubišová, Vlasta [1990]. Velká francouzská revoluce a Evropa 1989-1800. Prague: Svoboda.

2 All documents are kept by the National Archives of the Czech Republic, Prague, the fund of the Archives of the Czech Gubernium. 
Jackob, Nikolaus [2007]. Cicero and the Opinion of the People: The Nature, Role and Power of Public Opinion in the Late Roman Republic. Journal of Elections, Public Opinion and Parties 17 (3): 293-311.

Madl, Claire - Tinková, Daniela (edd.) [2012]. Francouzský švindl svobody, francouzská revoluce a veřejné mínění v českých zemích. Prague: Argo.

Kramerius, Václav Matěj [1790-]. Kraméryusowy Cýs. K. Pražské Posstowské Nowiny [online]. Available from: <http://kramerius.nkp.cz/kramerius/PShowPeriodical.do?id=29153> [cit. 2. 5. 2016].

Kutnar, František [1946]. Proroctví v životě minulého lidu. Český lid 33 (9/10): 135-138.

Kutnar, František [1937]. Reakce státu v Čechách na Velkou francouzskou revoluci. Český časopis historický 43 (3-4): 323-342, 520-542.

Kutnar, František [1948a]. Cesta selského lidu ke svobodě. Prague: Československá akademie zemědělská.

Kutnar, František [1948b]. Sociálně myšlenková tvářnost obrozenského lidu: trojí pohled na český obrozenský lid jako př́spěvek k jeho duchovním dějinám. Prague: Historický klub.

Mejdřická, Květa [1959]. Čechy a francouzská revoluce. Prague: Naše vojsko.

Neubauer, Hans-Joachim [1999]. The Rumour: A Cultural History. London, New York: Free Association Books.

Novotný, Jan [1973]. Matěj Václav Kramerius. Prague: Melantrich.

Roubík, František [1923]. Ohlas francouzské revoluce na českém venkově roku 1793-1794 ve světle úředních zpráv. Časopis pro dějiny venkova 10: 176-181.

Svoboda, Miroslav [2012]. Reflexe Francouzské revoluce a napoleonských válek v kronikářských záznamech z moravského venkova. Pp. 237-283 in Madl, Claire - Tinková, Daniela (edd.). Francouzský švindl svobody, francouzská revoluce a veřejné mínění v českých zemích. Prague: Argo.

Tarde, Gabriel [1901]. L'Opinion at la Foule. Paris: Félix Alcan.

Tinková, Daniela [2012]. Ohyzda na prodej a "zmatení pojmů". Koncept svobody a rovnosti v protirevolučních brožurách z českých zemí. Pp. 101-142 in Madl, Claire - Tinková, Daniela (edd.). Francouzský švindl svobody, francouzská revoluce a veřejné míněnív českých zemích. Prague: Argo.

Vavák, František Jan [1907-1938]. Paměti Františka J. Vaváka, souseda a rychtáře milčického z let 1770-1816. Vol. 1-10. Prague: Dědictví sv. Jana Nepomuckého.

Volf, Josef [1935]. Dějiny novin a časopisů. Česká vlastivěda. Díl VII. Písemnictví. Prague: Sfinx.

Katerina Soukalová graduated with a doctoral degree in historical sociology at the Faculty of Humanities, Charles University, Prague in 2017. The subject of her dissertation research was the socio-psychological aspects of communication, rumors, gossip and misinformation.

Jiř Šubrt founded the Department of Historical Sociology at the Faculty of Humanities of Charles University in 2009. Over the longer term he has given attention to the issues of current sociological theory, public opinion, time and memory. He is the author and editor of several books published in the Czech, English and Russian languages. One of his latest books, under the title The Perspective of Historical Sociology, was published in the UK in 2017.

Jan Štemberk works at the Department of Historical Sociology, Faculty of Humanities, Charles University. After completing his master's degree in history, Slovenian studies and law, he continued his doctoral studies at the Department of Economic and Social History, Faculty of Arts, Charles University. In 2011, he gained his doctorate in the field of economic and social history. He is oriented towards modern economic and social history, focusing on the history of transport, tourism and economic administration. He is the author of four monographs and several dozen studies. 